\title{
Central America and the pandemic: macroeconomic policy challenges ${ }^{1}$
}

\author{
Juan Carlos Moreno Brid and Rodrigo Alfonso Morales López
}

\begin{abstract}
This article has a twofold purpose: to describe the social and economic situation in the countries of the Central American subregion prior to the coronavirus disease (COVID-19) pandemic and to provide a comparative analysis of the macroeconomic policies introduced by the governments of these countries in response to this health crisis. As a central part of that analysis, it looks at the main structural policy challenges for the enhancement of social protection and reactivation of production activity and employment to be met by these countries during and after the pandemic. The need for a national compact around a new development agenda is explored, with special emphasis on external elements that should be coupled with national policies, such as regional coordination, international cooperation and finance, and a restructuring of financial and lending institutions.
\end{abstract}

\section{Keywords}

COVID-19, virus, epidemics, economic aspects, macroeconomics, fiscal policy, monetary policy, gross domestic product, exports, tourism, remittances, poverty, regional cooperation, economic development, Central America

\section{JEL classification}

E52, E60, E62, H60

\section{Authors}

Juan Carlos Moreno Brid is a professor in the School of Economics of the Universidad Nacional Autónoma de México (UNAM). E-mail: juancarlosmorenobrid@gmail.com.

Rodrigo Alfonso Morales López is a postdoctoral researcher with the School of Economics of the Universidad Nacional Autónoma de México (UNAM). E-mail: ramorales88@gmail.com.

\footnotetext{
1 The authors wish to thank Abraham Pazos Rodríguez, Research Assistant, for his valuable contributions.
} 


\section{Introduction}

The coronavirus disease (COVID-19) pandemic has led to a double tragedy: death and sickness, on the one hand, and the collapse of production activity and employment and the resulting deterioration in people's living conditions, on the other. Its impact has plunged the Latin American economies into the deepest depression to overtake them in nearly 100 years. For Central America, the impact has been devastating. The lockdowns - which may be required numerous times, although no one knows for sure - have dealt a brutal blow given the high poverty rate, glaring inequality and prevalence of poorly paid informal working arrangements that do not provide adequate medical insurance or reserves to offset a loss of income. In addition, since these are small, very open, weakly industrialized economies, their performance hinges on their currently paralysed external sector. This balance-of-payments constraint is heightened by the pressure on macroeconomic policy being exerted by capital volatility and the unrelenting conditions imposed by rating agencies, which alter these economies' access to international finance from one day to the next.

The governments of the Central American countries were quick to grasp the seriousness of the pandemic and its repercussions. All of them except Nicaragua declared a state of emergency or its equivalent. Drawing on theoretical and practical macroeconomic lessons learned from pre-pandemic experiences, they first moved to adopt measures to reinforce the health sector, distributed health information and issued lockdown orders, mandated social distancing requirements and put other safeguards in place. Once those steps had been taken, their next move was to introduce countercyclical fiscal and monetary policies.

This article will review the status of macroeconomic policy in the countries of Central America as they grapple with the pandemic. The second section will look at the main features of the economic situation in Central America just before the outbreak of this health emergency and the international crisis to which it has given rise. It will also trace the channels through which the COVID-19 crisis has impacted the subregion. The third section will analyse the main macroeconomic responses which, to varying degrees and with varying scope, have been mounted by the Central American governments. The article closes with a series of observations about the lessons to be learned by the subregion from the pandemic and the resulting economic crisis. Without getting ahead of the analysis to be presented here, it can nonetheless be affirmed that the subregion has been put on notice that it must alter the development path that it, like the rest of the world, has been following. In order to heed this warning, it must take steps, as a matter of urgency, to enter into a regional compact to support a steady, sustainable and inclusive form of growth based on a new development agenda.

\section{Central America: the background of this twofold crisis and its vectors of transmission}

When the pandemic hit Latin America in early 2020, its economy was stalled. As an average for the region, real gross domestic product (GDP) for 2019 had shown no growth over the preceding 12 months. Central America's economy, on the other hand, had exhibited moderate growth, with its real GDP expanding, on average, by $2.5 \%$ albeit with considerable differences across the countries of that subregion. Guatemala's and Panama's economies were growing by slightly more than 3.0\% and those of Costa Rica, El Salvador and Honduras by slightly less (between 2.0\% and 3.0\%), while Nicaragua, which has been immersed in a deep economic and political crisis since 2018, saw its GDP plummet by $4 \%$ for the year (ECLAC, 2020a). 
The balance of payments exerts a strong influence on the economies of this subregion. Since these economies are small and very open, their performance is largely determined by the nature of their positions in today's globalized markets. If world trade is sluggish, the subregion's economies will languish. Another factor underlying their slow pace of growth during this period is the lack of a sustained upswing in gross fixed capital formation. According to the data available in CEPALSTAT (ECLAC, 2020i), real investment contracted by an average of $1.7 \%$ in 2019 in response to the prevailing uncertainty fueled by tense trade relations between the United States and China, Brexit, oil price volatility and mounting protectionism in the developed world. The situation was further exacerbated by the political crisis in Nicaragua, some measure of institutional instability in Honduras and political tensions in Costa Rica.

On the public finance front, according to data from the Economic Commission for Latin America and the Caribbean (ECLAC, 2020b), Latin America's public deficit in 2019 averaged 3.1\% of GDP, with only Costa Rica and Panama registering higher levels (6.9\% and 3.7\%, respectively). The fiscal space available to the subregion, which was to some extent reflected in the public debt as a percentage of GDP, varied from country to country but averaged $47.5 \%$. At the national level, this quotient was $26.1 \%$ in Guatemala, 37.5\% in Nicaragua, 46.4\% in Panama and 49.1\% in Honduras. El Salvador (67.4\%) and Costa Rica $(58.5 \%)$ had somewhat less manoeuvring room in this connection than their neighbours, which influences, but does not determine, their ability to implement countercyclical policies. Inflation has been under control for some time now.

On the social front, data stored in CEPALSTAT (ECLAC, 2020i) and recorded by ECLAC (2020a) indicate that poverty levels trended downward between 2012 and 2019 (except in Nicaragua) but nonetheless remained high at 33.7\% in El Salvador, 48.6\% in Guatemala, 54.8\% in Honduras and 47.1\% in Nicaragua. Costa Rica (16.5\%) and Panama (14.6\%) were the only countries in this subregion to report poverty rates below $20 \%$. The extent of inequality is similar in all the countries of this subregion. The Gini coefficient for 2018 was 0.40 for El Salvador, 0.48 for Honduras, 0.49 for Costa Rica and 0.50 for Panama, while the latest statistics available (2014) for Guatemala and Nicaragua put their Gini coefficients at 0.54 and 0.50 , respectively.

In sum, the subregion's pace of growth was moderate when the pandemic broke out and it was not troubled by inflationary pressures. Public finances, although complex, were not a cause of concern even though the countries' fiscal space was limited. Nonetheless, the subregion had high levels of poverty, inequality and undernutrition, and its health system was not robust. The challenges posed by the pandemic far outweigh those associated with the global financial crisis of 2008-2009 (World Bank, 2020).

The pandemic that began in China and then spread to neighbouring countries and the industrialized world has become an even more serious problem in developing economies such as those of Central America. One factor has been that the already alarming levels of poverty and inequality in these countries rose even further with the introduction of lockdowns and the subsequent deep reductions in employment and remunerations. In many countries, years' worth of the progress made in combating poverty and expanding educational coverage, as well as in other areas, are being wiped out. The reason why the pandemic has had such a stronger impact on some countries than others lies in such factors as these countries' chronic problems with their social security systems, their high morbidity rates, the lack of automatic stabilizers, the huge size of their informal labour markets and the scale of the precarious informal sectors of their economies, which have very low banking penetration rates.

The subregion also labours under the effects of having a low tax ratio and regressive tax structure, with tax receipts in some of the countries tending to hinge on export earnings from commodities whose prices are volatile on international markets. Their position in the global economy, which is founded on commodity exports or maquilas, amplifies the constraint on the Central American economies' growth generated by the balance of payments. This reliance on external demand and the terms of trade makes these countries' economies incapable of achieving the high, sustained growth rates needed to absorb their expanding workforce and reduce the prevalence of informal employment conditions. 
The pandemic has dealt a tremendous blow to aggregate supply and demand. It has also dampened inter-institutional flows of funds, weighed heavily on corporate balance sheets and household budgets, clouded the business climate, curbed domestic and foreign investment and added further to the power wielded by credit rating agencies. The first impact in the subregion was seen with the introduction of lockdowns, social distancing and restrictions on mobility. The suspension of works, the closure of businesses and wage cuts slashed expenditure and depressed production activity even further. All this has undermined the well-being of the entire population (although the impact has been far from evenly distributed), including the middle class, many of whose members have lost their formal-sector jobs and benefits. The upshot has been higher poverty levels and deepening inequality.

External constraints on the subregion's economic growth have tightened with the advent of the pandemic. Its impact has been transmitted through the various components of both the current and capital accounts on the balance of payments. Lockdowns and recessions in the developed world - and particularly the United States - have stifled exports, disrupted global supply chains, smothered tourism and caused remittances to plummet, thereby undercutting Central America's main sources of foreign exchange. The situation has been exacerbated by the decrease in foreign investment inflows to developing economies, in particular. And all this is compounded by capital flight and limited access to international financing. While imports have also fallen as a result of the slowing of economic activity, the balance of payments continues to constrain the outlook for an economic recovery. This puts the dollarized economies of El Salvador and Panama at an even greater risk because they are unable to adjust their nominal exchange rates in order to blunt the effect of external shocks.

Central America is particularly vulnerable to the impacts of the pandemic in a number of ways. Its exports account for a larger percentage of GDP (between 22.2\% of GDP in Guatemala and $51.2 \%$ of GDP in Panama), on average, than is the case for the rest of Latin America (see table 1). According to the trade statistics compiled by the Secretariat for Central American Economic Integration (SIECA, 2020), $34 \%$ of the subregion's total exports of goods went to the United States in 2019. Intraregional exports are also significant, accounting for another $31 \%$ of those exports. ${ }^{2}$

Table 1

Central America: contribution of exports, tourism and remittances to GDP, 2019 (Percentages of GDP)

\begin{tabular}{cccr}
\hline Country & Exports & Tourism & Remittances \\
\hline Latin America & 20.4 & 8.1 & $1.7^{\mathrm{a}}$ \\
\hline Costa Rica & 37.5 & 12.0 & 0.8 \\
\hline El Salvador & 29.7 & 11.0 & 20.9 \\
\hline Guatemala & 22.2 & 6.2 & 13.7 \\
\hline Honduras & 45.7 & 11.7 & 21.6 \\
\hline Nicaragua & 49.0 & 10.1 & 13.2 \\
\hline Panama & 51.2 & 13.6 & 0.7 \\
\hline
\end{tabular}

Source: Prepared by the authors, on the basis of Economic Commission for Latin America and the Caribbean (ECLAC), CEPALSTAT, 2020 [online database] http://interwp.cepal.org/cepalstat/portada.html?idioma=english; ECLAC, Estudio económico de América Central y la República Dominicana en 2019 y perspectivas para 2020 (LC/MEX/TS.2020/29), Mexico City, 2020, and World Travel and Tourism Council (WTTC), "Economic Impact Reports" [online] https://wttc.org/Research/ Economic-Impact.

a Corresponds to 2018.

The weakening of external demand is also putting downward pressure on the prices of a wide range of commodities and other products sold by the subregion. The figures for January-May 2020 show year-on-year increases in the prices commanded by some key export products, however. For example,

2 The figures published by SIECA do not include free-zone or maquila exports. 
Costa Rica registered an upswing in the prices of its exports of medical devices, while Guatemala, Honduras and Nicaragua have reported rising prices for some agricultural or mineral exports, such as bananas and gold.

Exports of farm goods have been hurt somewhat less than other products because of the low income elasticity of external demand for foodstuffs (ECLAC, 2020c). It is still too soon to know if the higher prices for some types of export products will last or not, however. On the other side of the coin, the decline in energy prices has considerably reduced Central America's import costs. In monitoring price trends for agricultural and mineral products and for petroleum, it will be important to keep an eye on changes in the subregion's terms of trade as well.

The biggest impact that the pandemic has had on service exports has been in the tourism sector owing to mobility restrictions and the added risk of contagion associated with travelling. No prospect of a robust recovery appears to be on the horizon in the short run. As tourism gradually reactivates, people are expected to show a preference for short trips, which could give a boost to domestic and regional travel. The countries for which tourism is the most important in terms of its share of GDP are Panama (13.6\%), Costa Rica (12.0\%) and Honduras (11.7\%). The tourism sector's contribution to employment and service exports is equally significant. In 2014-2018, tourism accounted for $22.4 \%$ of Panama's service exports and 12.2\% of employment in Costa Rica (Mooney and Zegarra, 2020).

The reduction in family remittances that can be expected as part of the fallout from the deteriorating situation in the United States labour market is another blow for Central America, although its severity differs across the countries of the subregion. In El Salvador, Guatemala, Honduras and Nicaragua, 2019 remittances amounted to between 13.2\% (Nicaragua) and 21.6\% (Honduras) of GDP, whereas, in Costa Rica and Panama, they were less than 1\%. In net terms, these latter two countries tend to be sources, rather than destinations, for these kinds of remittances, at least during times of economic growth. After having fallen sharply, the level of remittances to El Salvador, Guatemala and Honduras has been moving back up since June 2020 (ECLAC, 2020a). Trends for the second part of the year will be determined by factors that are difficult to predict. The health, economic and even political situations in the United States are a source of risk, as is the prevailing uncertainty about the continuation of special support measures for workers, which are a pillar of countercyclical policy. In addition, exchange-rate variations will also influence purchasing power in destination countries.

Disruptions of global value chains caused by the pandemic are also reducing Central America's access to intermediate inputs needed for the production of both domestic consumer goods and exports. El Salvador, Honduras and Nicaragua are the countries in the subregion that rely most heavily on imported inputs, while Panama will see a considerable drop in its revenues from the operations of the Panama Canal and the Colón Free Zone (Castellani and others, 2020).

In addition to the effects described above, the pandemic has triggered greater volatility and risk perception in financial markets. The Emerging Markets Bond Index (EMBI) - which measures the spread between the interest rates paid on bonds issued by developing countries and the rates paid on United States Treasury bonds - reflects a deterioration in both the subregion and the developing world as a whole. Data from the Central Bank of the Dominican Republic (2020) for February-September 2020 indicate that country risk as measured by the EMBI rose by $31.8 \%$ in Latin America as a whole $(31.7 \%$ in Guatemala, 52\% in Honduras, 52.9\% in Panama, 54.7\% in Costa Rica and $111.7 \%$ in El Salvador). El Salvador's country risk is thus the highest in the subregion (841 basis points) - no data are available for Nicaragua - followed by Costa Rica (667), Honduras (398), Guatemala (323) and Panama (203), compared to a regional aggregate of 441 for Latin America. For the rest of the year, the difficulty in gaining access to external financing will no doubt only increase further, and there is no way that the low interest rates being paid in international markets will offset the impact that increased country risk will have on the cost of financing for the subregion. 
This is dampening flows of foreign direct investment (FDI) to Central America and may eventually trigger massive capital flight. In the first quarter of 2020 - when the full force of the pandemic was not yet being felt - official figures pointed to falling levels of FDI in all the Central American countries. CEPALSTAT data (ECLAC, 2020i) show that the year-on-year drop in FDI for that period amounted to 90.9\% in El Salvador, 11.6\% in Guatemala, 9.1\% in Costa Rica, 5.1\% in Panama and 1.5\% in Honduras, and the decline is quite likely to have continued throughout the rest of the year.

This situation has repercussions on public finances. While expenditure levels have been raised to cover the increased needs associated with the pandemic, revenues have dwindled as the pace of domestic economic activity and foreign trade slows. The hardening of lending terms and conditions darkens the horizon, and currency depreciations are elevating the debt-to-GDP ratio, which tends to reduce governments' fiscal space. In this type of situation, governments need to ensure that public investment does not act as the adjustment variable. On the contrary, they should try to strengthen investment in order to mitigate the drop in present demand and help change their countries' production patterns in the medium and long terms so that they can set out on a rapid, sustainable and inclusive growth path.

The investment climate is being hurt by the overwhelming impact of slumping sales, business closures and uncertainty about the outcome of the pandemic and future trends in key variables of the national and world economies. By the same token, private-sector consumption is declining as people's incomes fall and so many lose their jobs, as well as because they are becoming more cautious.

These negative impacts are distributed unevenly over different economic sectors and population groups. Tourism, the culture industry, retail trade, hotels and restaurants, transport and the textiles sector are being hit the hardest (ECLAC, 2020e). One of the most vulnerable groups in the population is made up of women whose situation is made more difficult by the absence of a care economy and by domestic violence, which tends to become more prevalent when people are forced to live in close quarters and when their incomes are reduced. Lower-middle-income groups run the risk of falling below the poverty line, which would wipe out the progress that it has taken the middle class years to achieve. Informal-sector workers -including those in domestic service- begin to have new and different kinds of needs and to experience new health risks when support programmes do not respond to their needs and risks properly. Children's and adolescents' access to a quality education is reduced or lost altogether, to say nothing of the support for the full personal development of the individual that they need at these stages in life. Many of them may drop out of school so that they can work to help out their families as household incomes shrink. The list of groups experiencing serious shortcomings is long and includes older adults, rural residents, indigenous peoples and persons of African descent, persons with disabilities, migrants, homeless persons and others (ECLAC, 2020f).

The ultimate scale of these various impacts on the Central American economies will depend on the path taken by the pandemic, the measures adopted by the countries and their success in designing appropriate economic policies for implementation over the medium and long terms. The following section will explore the economic policy responses, especially in the fiscal and monetary realms, that the governments of the subregion have set into motion in order to deal with this emergency.

\section{Macroeconomic policy responses to the pandemic}

The governments of the subregion have begun to adopt extraordinary measures to deal with this grave situation. They have mobilized resources for health care, imposed restrictions on people's movements and on production and commercial activities, and have put a stop to community and social life as we 
used to know it. In line with Keynes' teachings, they have introduced countercyclical policies. This section will focus on the most significant types of macroeconomic policies under these conditions: fiscal and monetary/financial policies. ${ }^{3}$ Table 2 provides a classification of these policy responses.

Table 2

Central America: policies adopted to address the COVID-19 crisis

\begin{tabular}{|c|c|c|c|c|c|c|c|}
\hline Type of policy & Measure & Costa Rica & El Salvador & Guatemala & Honduras & Nicaragua & Panama \\
\hline \multirow[t]{6}{*}{ Fiscal policy } & Temporary changes in tax collections & $x$ & $x$ & $x$ & $x$ & & $x$ \\
\hline & Public transfers & $x$ & $x$ & $x$ & $x$ & $x$ & $x$ \\
\hline & Deferral of service fees & $x$ & $x$ & $x$ & $x$ & $x$ & $x$ \\
\hline & Pay raises in the public sector & & $x$ & & & & \\
\hline & Physical investment & $x$ & $x$ & $x$ & $x$ & & $x$ \\
\hline & Public bond issues & $x$ & $x$ & $x$ & $x$ & & $x$ \\
\hline \multirow{7}{*}{$\begin{array}{l}\text { Monetary and } \\
\text { credit policy }\end{array}$} & Lowering of monetary policy rate & $x$ & & $x$ & $x$ & $x$ & \\
\hline & Alteration of bank reserve requirement & $x$ & $x$ & $x$ & & $x$ & \\
\hline & Other liquidity-boosting measures & $x$ & & $x$ & $x$ & & \\
\hline & Loan moratorium and restructuring & $x$ & $x$ & $x$ & $x$ & & $x$ \\
\hline & Freeze on credit ratings and streamlining & $x$ & $x$ & & $x$ & & \\
\hline & Creation of new lines of credit & $x$ & $x$ & $x$ & $x$ & & $x$ \\
\hline & Exchange rate interventions & & & $x$ & & & \\
\hline \multirow[t]{2}{*}{ Other } & Price controls & $x$ & $x$ & $x$ & $x$ & & $x$ \\
\hline & Direct intervention in the labour market & $x$ & $x$ & $x$ & $x$ & & $x$ \\
\hline
\end{tabular}

Source: Prepared by the authors, on the basis of A. Matarrita and R. Romero, "Políticas económicas implementadas en la región CAPARD para contrarrestar el impacto del COVID-19", Notas Económicas Regionales, No. 114, San José, Executive Secretariat of the Central American Monetary Council, June, 2020; Economic Commission for Latin America and the Caribbean (ECLAC), "COVID-19 Observatory in Latin America and the Caribbean: economic and social impact”, 2020 [online] https://www.cepal.org/en/topics/covid-19; International Monetary Fund (IMF), "Policy Responses to COVID-19", 2020 [online] https://www.imf.org/en/Topics/imf-and-covid19/Policy-Responses-to-COVID-19; Central Bank of Honduras, "El Banco Central de Honduras revisa el programa monetario 2020-2021 y aprueba una nueva reducción en su tasa de política", Boletín de Prensa, No. 42/2020, Tegucigalpa, 31 July 2020; Bank of Guatemala, "La Junta Monetaria por unanimidad reduce en 25 puntos básicos la tasa de interés líder de política monetaria", Boletín de Prensa, Guatemala City, 25 June 2020; Ministry of Finance of El Salvador, Estimación de los costos económicos, sociales, fiscales y medidas adoptadas en el marco de la pandemia COVID-19, San Salvador, April 2020, and Ministry of Employment and Labour Development of Panamá, "Reglamentan la suspensión de los contratos de trabajo", 20 March 2020 [online] https://www.mitradel.gob.pa/reglamentan-la-suspension-de-los-contratos-de-trabajo-2/.

Costa Rica, Guatemala and Honduras have made use of a wide array of fiscal, monetary and credit policies. Nicaragua's response has been weak and clearly insufficient. Since Panama and El Salvador have dollarized economies, their main responses have taken the form of fiscal and credit supports. On the fiscal front, as may be seen from table 3, the authorities' countercyclical stance in 2020 can be expected to result in lower-than-budgeted tax revenues. By the same token, increases in public expenditure and the fiscal deficit are projected for all the countries of the subregion. The combination of a contraction in production activity and the implementation of countercyclical policies entailing both higher spending levels and lower tax receipts in some categories - owing, up to a point, to endogenous factors - will result in a considerable increase in the ratio of public debt to GDP in 2020. The change in this ratio will be larger in the non-dollarized economies if sizeable exchange rate depreciations occur throughout the year.

3 A detailed list and description of the wide range of economic and social policy responses mounted by each country of the region in response to the pandemic is available from the ECLAC COVID-19 Observatory in Latin America and the Caribbean at: [online] https://www.cepal.org/en/topics/covid-19. Information for the countries of the world is available at the following websites: https://www.imf.org/external/spanish/index.htm (International Monetary Fund (IMF) and https://www.bancomundial. org/ (World Bank). 
Table 3

Central America: variations in the main fiscal indicators, 2020

(Percentages of GDP)

\begin{tabular}{|c|c|c|c|c|c|c|}
\hline Indicator & Costa Rica & El Salvador & Guatemala & Honduras & Nicaragua & Panama \\
\hline \multicolumn{7}{|l|}{ Tax revenues } \\
\hline Budgeted & 13.3 & 18.2 & 10.4 & 16.8 & 17.2 & 7.7 \\
\hline Closing estimate & 12.6 & 17.1 & 9.8 & 15.8 & 17.0 & 7.0 \\
\hline Expected loss (percentage points) & 0.7 & 1.1 & 0.5 & 1.0 & 0.2 & 0.7 \\
\hline \multicolumn{7}{|l|}{ Total expenditure } \\
\hline Budgeted & 22.1 & 22.1 & 13.8 & 18.4 & 18.9 & 15.5 \\
\hline Closing estimate & 22.6 & 28.6 & 16.3 & 21.6 & 19.4 & 22.0 \\
\hline Expected increase (percentage points) & 0.5 & 6.5 & 2.5 & 3.2 & 0.5 & 6.4 \\
\hline \multicolumn{7}{|l|}{ Fiscal deficit } \\
\hline Budgeted & -7.9 & -1.9 & -2.6 & -2.0 & 0.0 & -3.1 \\
\hline Closing estimate & -8.3 & -11.9 & -5.8 & -6.4 & -0.8 & -6.2 \\
\hline Expected increase (percentage points) & -0.4 & -10.0 & -3.3 & -4.4 & -0.9 & -3.1 \\
\hline \multicolumn{7}{|l|}{ Public debt } \\
\hline Budgeted & 62.8 & 71.1 & 27.3 & 51.2 & 35.9 & 46.8 \\
\hline Closing estimate & 67.2 & 92.1 & 31.7 & 56.7 & 38.0 & 56.2 \\
\hline Expected increase (percentage points) & 4.5 & 21.0 & 4.4 & 5.6 & 2.0 & 9.3 \\
\hline
\end{tabular}

Source: Central American Institute for Fiscal Studies (ICEFI), "Estimación de la situación fiscal de Centroamérica al final de 2020", Notas de Coyuntura, No. 05-2020, Guatemala, July 2020.

Projections computed by the Central American Institute for Fiscal Studies (ICEFI, 2020b) indicate that central government debt will climb to $57 \%$ of GDP, on average, which is 8 percentage points of GDP higher than the budgeted figures. The steepest upswing, of 21 percentage points, will be seen in El Salvador, whose debt is expected to top 90\% of GDP. In the other countries, the increase will be in the single digits, with the sharpest being in Panama ( 9 percentage points), followed by Honduras (6 percentage points), taking these two countries' debt levels to the equivalent of $56 \%$ of their respective GDP totals. For Guatemala and Costa Rica, the ratio is expected to climb by around 4.5 percentage points to $32 \%$ and $67 \%$, respectively. Nicaragua's debt will hold almost steady relative to GDP, with an increase of just 2 percentage points bringing its ratio to $38 \%$.

This unusually large upswing in the public debt reflects the expansion of the fiscal deficit. In all the countries, this shortfall will outstrip the approved deficit levels set in their national budgets, ranging from less than 1 percentage point in the cases of Costa Rica (-0.4\%) and Nicaragua (-0.9\%) and under 4 percentage points or around that figure in Panama (-3.1\%), Guatemala (-3.3\%) and Honduras (-4.4\%) to $10 \%$ in El Salvador. In all the countries except Costa Rica, the growth of the fiscal deficit will be more an effect of higher spending than of lower tax receipts, as the reduction in the latter is expected to be quite small in 2020 (between $0.2 \%$ and 1.1\% of the corresponding country's GDP) (ICEFI, 2020b). These contractions are not just the result of slackening activity; countercyclical tax incentives are also a factor. The overages in spending (relative to initial projections) are fairly similar across the countries of the subregion. ICEFI (2020b) estimates put this "excess" expenditure at half a percentage point of GDP for Costa Rica and Nicaragua, which is in step with the fairly limited increase in their fiscal deficits. For Guatemala and Honduras, the project increases are 2.5 and 3.2 percentage points of GDP, respectively, while the steepest rise (6.5 percentage points) is expected in El Salvador.

Some of the main countercyclical fiscal measures adopted by the Central American countries on varying scales and at different points in time will be examined in greater detail in the following discussion, including temporary modifications in tax collections involving tax credits, waivers, amnesties, exemptions, reductions and deferrals. 
Fiscal support measures have been introduced to assist individuals, families and businesses that are vulnerable or have already been impacted by these extraordinary circumstances. ${ }^{4}$ In Costa Rica, transfers have been made to persons living in poverty and food and biosafety packages have been distributed to persons with disabilities, people living in extreme poverty, older adults and the unemployed. In El Salvador, US\$300 per family has been distributed to 1.5 million households, and 1 million food packages have been delivered. In Guatemala, targeted transfers of US\$130/month have been granted for a period of three months and assistance allowances have been made available to persons in the informal sector, pensioners and health workers. Packages of food, medicines and other inputs have been delivered to vulnerable persons. In Honduras, transfer payments have been made to transport workers, and packages containing food and personal hygiene items have been distributed. In Panama, vouchers for the purchase of food, medicines and petrol have been provided in urban areas and packages of these items have been distributed in rural areas. In Nicaragua, the only official reports of assistance deal with the distribution of food packages in various areas of the country. As an additional measure, some countries have subsidized basic services. Measures have also been introduced in the labour market. In El Salvador, for example, a US\$150 wage hike for civil servants directly involved in combating the pandemic has been approved. Increased fiscal assistance measures for households have, for the most part, taken the form of monetary or in-kind transfers.

In addition to the measures adopted to buoy household consumption, various kinds of steps have also been taken to help businesses maintain employment levels and to shore up their production capacity. In Costa Rica, temporary public transfer payments have been made to microenterprises and to small and medium-sized enterprises (MSMEs) in the fishery, tourism and farm sectors. The taxes paid by airlines on the fares that they sell have been suspended for four months and the annual tax fees levied on businesses in the fishery sector have been suspended for three months. In Guatemala, a three-month moratorium on corporate tax payments has been declared, and the contributions to be paid by employers to the Private Enterprise Workers' Recreation Institute (IRTRA), the Technical Training and Productivity Institute (INTECAP) and the Social Security Institute of Guatemala (IGSS) have all been suspended for three months as well. In Honduras, tax payment deferrals have been granted to businesses classified as small or medium-sized enterprises. In Panama, all tax payments have been deferred for 120 days. Subsidies have been granted in El Salvador to firms employing 100 or fewer employees to cover $50 \%$ of their wage bill for up to two months, and the special tax levied on tourism companies has been deferred. In addition to all these fiscal measures, companies have received different kinds of financial assistance, as will be discussed in greater detail below. The only country in the subregion that has not introduced fiscal support measures for businesses is Nicaragua.

Other fiscal measures have benefited households and companies alike. For example, Costa Rica has declared a moratorium on income taxes and value added taxes and has lowered the tax floor for social security payments by $75 \%$ for employers, independent workers and public-sector employees. In El Salvador, income tax payments have been deferred for both individuals and institutions. Honduras has deferred all tax payments for small and medium-sized taxpayers until June 2020 and income tax payments until August, in addition to instituting an $8.5 \%$ income tax cut for this category of taxpayer, while Panama has deferred tax payments for 120 days.

The governments of the subregion have needed additional financing to fund special programmes and other responses to the twofold emergency. Major external sources have included the International Monetary Fund (IMF), World Bank, Inter-American Development Bank (IDB) and Central American Bank for Economic Integration (CABEl). For the subregion as a whole, the biggest disbursements have been made by IMF (US\$2.145 billion) and the World Bank (US\$2.025 billion). CABEI has also

4 Information on fiscal measures has been obtained from the following sources: Matarrita and Romero (2020), ECLAC (2020f), IMF (2020) and the Ministry of Finance of El Salvador (2020). 
provided large sums of financing (US\$1.453 billion). According to ECLAC data (2020a), the countries that have issued the most debt paper are Costa Rica (US\$1.679 billion), Honduras (US\$1.169 billion) and Panama (US\$1.065 billion).

One limitation of the initial strategy for coping with the emergency has been that - as is to be expected - the countries have focused their fiscal stimulus packages on steps that needed to be taken in the short run, while putting off the design of a post-emergency strategy to ensure the sustainability of the countries' debt profiles in line with a new sustainable, inclusive long-term development agenda.

The public budgets being drawn up for 2021 should include plans for backstopping a sustained and sustainable economic recovery in the medium and long terms. As of September 2020, only Costa Rica, Guatemala, Honduras and Panama had unveiled their draft budgets for 2021.5 The draft budgets of Guatemala and Honduras include multi-annual guidelines up to 2023, but the amounts set out for the fiscal effort to deal with the consequences of the crisis over the medium term may fall short of what is needed. ${ }^{6}$ What is more, both countries plan to resort to fiscal consolidation measures in order to counterbalance the impact on public finances. Costa Rica has proposed strong fiscal consolidation measures for 2021 and, as of September, was negotiating an agreement with IMF that would call for major public spending cuts and asset sales in the medium term. The subregion thus runs the risk of making a far too premature return to austerity policies that would lengthen and deepen the recession, further worsen conditions in the labour market and, as a result, raise their societies' levels of poverty and inequality.

In the area of monetary and credit policy, the Central American countries' main responses have taken the form of reductions in interest rates and bank reserve requirements and measures designed to ease access to credit. ${ }^{7}$ Inflation rates are low enough to provide room for the conventional types of expansionary monetary policies. According to data compiled by the Executive Secretariat of the Central American Monetary Council (SECMCA, 2020), between February and September 2020, Costa Rica cut its rate by 450 basis points (from 5.25\% to $0.75 \%$ ), Guatemala by 100 basis points (from $2.75 \%$ to $1.75 \%$ ) and Honduras by 150 basis points (form 5.25\% to $3.75 \%$ ). Nicaragua set its monetary policy rate at $6 \%$ in April and then lowered it by 175 basis points in August 2020.

Some of the countries have modified their bank reserve requirements to buoy liquidity and encourage the domestic banking system to buy public debt securities. In Guatemala, the way in which the reserve requirement is to be calculated was changed to make it more flexible for a period of 180 days. Nicaragua lowered its legal reserve requirement by $10.5 \%$ for the whole of 2020 and, according to data from SECMCA (2020), El Salvador reduced its effective bank reserve requirement from $22.8 \%$ in February to $16.6 \%$ in July 2020. Other steps taken to boost liquidity include the purchase of 250 billion colones worth of government bonds on the secondary market by the Central Bank of Costa Rica. Guatemala is the only country to intervene in the currency market; it stepped in, with purchases of US\$ 400 million, in March 2020 to maintain the stability of its exchange rate.

As inflation has remained low, interest rate cuts and injections of liquidity have taken effect in real terms. Nevertheless, the fact remains that the effectiveness of conventional expansionary monetary policy tools is extremely limited during times of crisis because of investors' very subdued expectations of future profits and because of the highly concentrated and shallow nature of the subregion's financial markets.

5 See Ministry of Finance of Costa Rica (2020), Ministry of Finance of Honduras (2020a and 2020b), Ministry of Public Finance of Guatemala (2020) and Ministry of Economic Affairs and Finance of Panamá (2020).

6 Guatemala's draft general government budget for 2021 puts the cost of the special measures envisaged for mitigating the damage caused by the crisis at $2.9 \%$ of the total amount allocated for the entire year (Ministry of Public Finance of Guatemala, 2020).

7 Information on monetary and credit measures is drawn from Matarrita and Romero (2020), ECLAC (2020f), IMF (2020), Bank of Guatemala (2020) and Central Bank of Honduras (2020). 
Most of the countries have coupled expansionary monetary policies with measures to make credit more readily available and with offers of more attractive terms for households and businesses. In Costa Rica, a special line of credit for financial intermediaries of 700 billion colones has been opened up along with another line for MSMEs to provide them with seed capital and to enable them to buy intermediate inputs or cover their payrolls. El Salvador has created a US\$ 600 million trust fund to support MSMEs and the informal sector. Honduras has also created a trust fund to facilitate credit access for MSMEs. Guatemala has established a credit line of 100 million quetzales for MSMEs, and Panama has set up a special fund for strengthening credit access that will supply US\$ 500 million for use in stabilizing the financial system and another US\$ 500 million for a credit line for the sectors that have been hit the hardest by the pandemic. Several countries have called moratoriums, have restructured personal and business loans and have frozen and/or regularized credit ratings. For example, Costa Rica has temporarily suspended the collection of interest on mortgages from the National Institute for Housing and Urban Affairs (INVU), and El Salvador has declared a moratorium on payments on bank loans in order to provide financial support for the farm sector.

In addition to these macroeconomic measures, other tools have been used to control the prices of key goods or to institute new regulations in the labour market, for example. All the countries except Nicaragua have put price controls on staples in place. Some have also introduced price controls for personal hygiene and biosafety products. Direct interventions in the labour market have included Costa Rica's creation of a temporary subsidy for workers impacted by the health emergency and El Salvador's passage of an employment protection law ${ }^{8}$ that provides for temporary safeguards to maintain job stability in the private sector.

It takes a considerable fiscal effort to implement economic policies that will counteract the negative impact of this crisis on the Central American economies. ${ }^{9}$ The magnitude of the measures announced by the countries to make that effort ranges from 0.8\% of GDP in Costa Rica to $11.1 \%$ of GDP in El Salvador, with those of the other countries coming in at $4.3 \%$ of GDP in Honduras, $2.5 \%$ in Guatemala and 3.7\% in Panama (ECLAC, 2020d). No data are available for Nicaragua because it has not announced any fiscal stimulus programme.

The scale of this effort is not necessarily related to the amount of fiscal space that theoretically exists. Costa Rica and EI Salvador are having greater difficulties with their public finances, since their public debts, when measured as a percentage of GDP, amounted to over 70\% in 2019 (ICEFI, 2020a), and the size of their fiscal packages, again in terms of GDP, marks a sharp contrast. The success of countercyclical measures is not determined solely by the total amount that is spent on them, however, since their composition and timing are also influential factors. Proper planning based on reliable, relevant statistical records is also important, as is transparency in these measures' implementation and a clear accounting of how public monies are being used.

In the midst of a crisis, fiscal and monetary policies need to be closely coordinated. Fiscal policy should take a leading role in spurring production activity, while monetary policy should ensure the availability of financing at the lowest cost possible as the fiscal deficit inevitably expands (Panico, 2020). El Salvador and Panama both have dollarized economies, which makes it impossible to coordinate these policies. Costa Rica, Guatemala and Honduras, on the other hand, have -albeit to differing degrees - coordinated their implementation of expansionary fiscal and monetary policies in order to cope with the effects of the crisis.

\footnotetext{
8 See [online] https://www. diariooficial.gob.sv/diarios/do-2020/05-mayo/05-05-2020.pdf.

9 The final budget figures may differ because of restrictions on access to external finance. In addition, public debt issues are subject to congressional approval.
} 
It is important for fiscal policy to take the lead, not only in the short run to deal with immediate problems, but also in the medium and long terms to contribute to a robust, inclusive economic recovery. Consideration should therefore be given to the implementation of progressive, redistributive fiscal reforms and the minimization of tax avoidance and evasion in order to cope with the deterioration in public finances across the board. The design and execution of measures for overcoming external growth constraints are equally important, with examples of such measures including the regulation of capital flows and a policy for changing production patterns in ways that will increase the value-added content of exports.

Countercyclical policies cannot entirely absorb the immense force of the blow dealt by this twofold crisis, however, and estimates of economic activity, inequality and poverty levels for 2020 are not promising. The Monthly Index of Economic Activity (IMAE) for the Central American countries is already reflecting a steep downturn. Information from SECMCA (2020) indicates that the slump witnessed up to mid-2020 (according to the most recent figures available for each country as of September) has amounted to year-on-year declines of 9.5\% for Nicaragua as of April, 40.9\% for Panama as of May, $12.2 \%$ for El Salvador as of June, $13.4 \%$ for Honduras as of June, $8.1 \%$ for Costa Rica as of July and $4.8 \%$ for Guatemala as of July. As lockdowns and other restrictions are relaxed, the countries should gradually regain their former rates of economic activity. If there is a second wave of contagion, however, the impact will be devastating.

ECLAC projections (2020a) point to a steep drop in real GDP in all the countries of the subregion (see table 4), although the average estimated contraction for Central America of 5.9\% is much lower than the projected $9.1 \%$ downswing for Latin America and the Caribbean as a whole. The steepest decreases in the subregion are expected to be in El Salvador (-8.6\%) and Nicaragua (-8.3\%); the projection for Nicaragua is a cause of concern because such a sharp decline would only deepen a crisis that has already lasted for two years. An alternative indicator of the pandemic's effect on these economies' growth profiles which may be even more informative is the differential between their growth rates for 2019 and 2020. This measurement of the pandemic's impact would appear to indicate that the extent of the slowdowns in Central America and in Latin America and the Caribbean will, on average, be quite similar (8.4 percentage points for the former versus 9.1 points for the latter). Nevertheless, the rates of economic activity will fall sharply in all of them: El Salvador (-11.0 percentage points), Panama (-9.5), Honduras (-8.8), Guatemala (-7.9) and Costa Rica (-7.6). Nicaragua is expected to have the smallest decrease, but starting from the low point set by a significant recession in 2019. Clearly, however, the impact of the pandemic on economic activity would have been much greater if it had not been for the countercyclical policies that have been put in place.

Table 4

Central America: real GDP growth rates, 2019 and 2020 (Percentages)

\begin{tabular}{lccc}
\hline Country & 2019 & $2020^{\mathrm{a}}$ & $\begin{array}{c}\text { Differential 2019-2020 } \\
\text { (Percentage points) }\end{array}$ \\
\hline Central America & 2.5 & -5.9 & 8.4 \\
\hline Costa Rica & 2.1 & -5.5 & 7.6 \\
\hline El Salvador & 2.4 & -8.6 & 11.0 \\
\hline Guatemala & 3.8 & -4.1 & 7.9 \\
\hline Honduras & 2.7 & -6.1 & 8.8 \\
\hline Nicaragua & -3.9 & -8.3 & 4.4 \\
\hline Panama & 3.0 & -6.5 & 9.5 \\
\hline Latin America and the Caribbean & 0.0 & -9.1 & 9.1 \\
\hline
\end{tabular}

Source: Prepared by the authors, on the basis of Economic Commission for Latin America and the Caribbean (ECLAC), CEPALSTAT, 2020 [online database] http://interwp.cepal.org/cepalstat/portada.html?idioma=english; Estudio económico de Centroamérica y la República Dominicana en 2019 y perspectivas para 2020 (LC/MEX/TS.2020/29), Mexico City, 2020, and "Addressing the growing impact of COVID-19 with a view to reactivation with equality: new projections", COVID-19 Special Report, No. 5, Santiago, 15 July, 2020.

a ECLAC projections. 
ECLAC (2020a) projects that real per capita GDP will fall by $7.1 \%$ in 2020 for the subregion as a whole, with the largest decreases being in El Salvador (-9.4\%) and Nicaragua (-9.2\%). This contraction will thus be so drastic that it will take Central America years to regain its pre-pandemic levels. The Economist Intelligence Unit projects that El Salvador and Guatemala will not reclaim their 2019 levels of GDP until 2023 (The Economist, 2020a and 2020b) and that Nicaragua will not even have returned to its 2017 level of GDP (reached prior to the country's 2018 sociopolitical crisis) by 2024 (The Economist, 2020c).

Table 5 shows projected poverty levels for 2020, which indicate that poverty and extreme poverty will rise in all the countries of the subregion. In Guatemala, El Salvador, Honduras and Nicaragua, these increases will outstrip the projected rises in Latin America as a whole.

Table 5

Central America: poverty and extreme poverty levels, 2019 and 2020

(Percentages)

\begin{tabular}{|c|c|c|c|c|}
\hline Indicator & Country & 2019 & $2020^{a}$ & $\begin{array}{c}\text { Differential 2020-2019 } \\
\text { (Percentage points) }\end{array}$ \\
\hline \multirow[t]{7}{*}{ Poverty } & Latin America & 30.2 & 37.3 & 7.1 \\
\hline & Costa Rica & 16.5 & 20.5 & 4.0 \\
\hline & El Salvador & 33.7 & 40.2 & 6.5 \\
\hline & Guatemala & 48.6 & 51.6 & 3.0 \\
\hline & Honduras & 54.8 & 59.0 & 4.2 \\
\hline & Nicaragua & 47.1 & 52.7 & 5.6 \\
\hline & Panama & 14.6 & 17.5 & 2.9 \\
\hline \multirow[t]{7}{*}{ Extreme poverty } & Latin America & 11.0 & 15.5 & 4.5 \\
\hline & Costa Rica & 3.4 & 5.1 & 1.7 \\
\hline & El Salvador & 7.4 & 11.9 & 4.5 \\
\hline & Guatemala & 19.8 & 22.7 & 2.9 \\
\hline & Honduras & 18.7 & 22.2 & 3.5 \\
\hline & Nicaragua & 18.0 & 22.8 & 4.8 \\
\hline & Panama & 6.5 & 8.5 & 2.0 \\
\hline
\end{tabular}

Source: Prepared by the authors, on the basis of Economic Commission for Latin America and the Caribbean (ECLAC), "Addressing the growing impact of COVID-19 with a view to reactivation with equality: new projections", COVID-19 Special Report, No. 5, Santiago, 15 July 2020.

a ECLAC projections.

El Salvador and Nicaragua are also the countries in which poverty and extreme poverty are expected to increase the most. This reversal will be a serious one and will wipe out the ground gained over years in the fight against poverty. The projected regression will mean that in 2020 the incidence of poverty will be similar to what it was in 2007 in Costa Rica, in 2015 in El Salvador, in 2014 in Guatemala, in 2013 in Honduras, in 2009 in Nicaragua and in 2015 in Panama (ECLAC, 2020d). Inequality is also expected to increase in all the countries, with the Gini coefficient projected to climb by between 5.0\% and 5.9\% in El Salvador, 3.0\% and 3.9\% in Costa Rica and Panama, 2.0\% and 2.9\% in Honduras and Nicaragua, and $1.0 \%$ and $1.9 \%$ in Guatemala (ECLAC, 2020d). Overall, Nicaragua and El Salvador are the countries that will be hurt the most by the crisis in terms of waning economic growth and rising poverty.

These projections of economic growth, poverty and inequality raise some question as to the efficacy of countercyclical policies. While the measures that have been implemented have, in general, been effective, a much greater effort will be needed going forward. So far this effort, measured as a percentage of GDP, has been insufficient in Costa Rica and negligible in Nicaragua. Given the magnitude of the crisis and the outlook for the future, the possibility that the countries might revert to austerity policies too soon is a cause of concern. It would be best if countercyclical fiscal policies are institutionalized through the creation of automatic stabilizers. These measures should also be framed within a vision of the future and directed towards protecting jobs, shielding vulnerable groups in the population and promoting changes in production patterns that will contribute to environmental sustainability and social inclusion. This point will be explored in greater depth in the following section. 


\section{Concluding remarks}

The governments of the subregion moved quickly to counter the brutal blow dealt by the pandemic. Initially, in addition to imposing lockdowns and social distancing measures, they provided support for the health care system and the material well-being of households and businesses. Once the restrictions were relaxed, their finance ministries, in coordination with their central banks and economic and social agencies, embraced Keynes' maxim: "The boom, not the slump, is the right time for austerity at the Treasury." 10 Accordingly, all of the countries except Nicaragua set up programmes - of differing scales in terms of scope and funding - that called for the expansion of public expenditure and the relaxation of monetary and financial conditions. The range of measures applied to date is quite broad, but they will not be enough to drive a robust recovery. GDP projections for 2020 and 2021 have repeatedly been revised downward, apparently foreshadowing a deep recession and slow reactivation. These revisions will continue to be subject to the uncertain outcome of the pandemic and the continuation or discontinuation of countercyclical measures.

While a good measure of uncertainty does surround public revenue and expenditure projections, there is no doubt about the fact that the primary and global fiscal balances will deteriorate and that the debt will swell, in part because of the contraction of GDP, the fact that tax revenues will lag behind emergency spending and the effect of exchange-rate depreciations. It is also inarguable that the fiscal space available to each of the countries in the subregion in 2021 will be much smaller than it was in 2020, and this greater limitation of fiscal manoeuvring room will coincide with much greater needs on the part of the population: as 2020 draws to a close, average per capita GDP in the subregion will have slipped back in real terms to the levels seen 10 or more years ago, millions of people will have lost their formal-sector jobs, and many will have seen their incomes dwindle and will fall below the poverty line. What is more, there are no signs of an economic recovery in 2021, other than perhaps in China and some other Asian countries, where an upswing in activity may be strong enough to make up for the present contraction.

Given these conditions, the subregion is confronted with formidable challenges in relation to its short-tern macroeconomic and social policies and its long-term development path. The first such challenge will be to refrain from prematurely withdrawing the countercyclical fiscal, monetary and financial stimulus measures targeting vulnerable groups in the population and those designed to buoy investment and production activity and to protect jobs. ${ }^{11}$ There is no shortage of examples in which an overly hasty return to austerity measures before an economic recovery has taken firm hold has prolonged a recession and deepened poverty and inequality. A central premise of macroeconomic policy should be that sustainable fiscal consolidation can only occur against the backdrop of a robust recovery of economic activity. Attempting to achieve such a consolidation, as has been done in the past, by prioritizing austerity measures and curbing or cutting public spending is counterproductive and extremely costly in social and economic terms. The longer and deeper a recession is, the more the debt-to-GDP ratio will tend to rise, rather than fall. ${ }^{12}$ The governments of the subregion should take this into account, especially since, even before the first wave of COVID-19 has been fully brought under control, a second wave appears to be in the making in a number of countries.

\footnotetext{
10 "Fiscal austerity and corporate cost-cutting would do nothing but worsen the globe's pre-existing conditions" (Kozul-Wright, quoted in UNCTAD, 2020b).

11 The United Nations Conference on Trade and Development (UNCTAD, 2020a) has warned that a return to austerity policies in 2021 would dampen the growth of production activity, increase unemployment and the labour gap, and reduce the share of labour income.

${ }^{12}$ For a reasoned analysis of the type of expansionary austerity proposed by Alesina, Favero and Giavazzi (2019) that is particularly relevant for Central America and other developing economies, see Skidelsky and Fraccaroli (2017) and Skidelsky (2019).
} 
Meeting this first challenge will require a fiscal commitment to, at the least, maintain existing public spending stimuli during this phase of the recession and to make them more effective and efficient. This will entail taking steps - or at least making a commitment - to augment tax and non-tax revenues and to give consideration to a support programme backed up by international financing. It is imperative for countercyclical spending initiatives to have high income and employment multipliers without putting excessive pressure on the balance of payments. Government revenues in the subregion are hurt by its low tax rates and the fact that its taxation systems are doing very little to bring about a more progressive redistribution of income. The governments should therefore consider increasing their borrowing levels, at least over an intermediate time horizon, to ensure that the subregion does not veer away from a path of sustainability. Dealing with this challenge will influence the degree to which the countries of the subregion will be able to maintain their countercyclical policy effort and the chances of setting the scene for a robust economic upswing. Because of the structural weakness of fiscal income sources, public investment has been the adjustment variable in the countries' efforts to cope with the pressure for fiscal consolidation, to the detriment of infrastructure, private investment growth and, in sum, the Central American economies' potential growth rate. Monetary authorities need to coordinate their actions in order to support this effort, and the Central American governments need to think about the possibility of having the central banking system play a more active role in financing development and, more specifically, public investment, as well as, in some cases, considering the possibility of entering into joint ventures with the private sector. As noted by Barbosa and others (2020), this way of financing the public debt may entail some risks in terms of macroeconomic stabilization in the medium term, but those risks are overshadowed by the threat that would otherwise be posed to the population's subsistence and to social peace.

The second challenge, which is not unrelated to the first, is a major political economy issue. A consensus needs to be reached by political, social and economic stakeholders - first in each nation and then in the subregion as a whole - to rewrite the development agenda. Just as this unprecedented emergency has demanded unprecedented economic and social policy responses, now unprecedented political agreements and economic strategies are called for in order to pull through the pandemic and the associated economic crisis and to place production activity and employment in Central America on a rapid and steady growth path. There is no returning to the pre-crisis status quo. Reverting to the same accumulation, production and distribution patterns as before is unthinkable and would be both negligent and irresponsible in the face of the inequality, exclusion and environmental issues that the subregion faces. These approaches have proven to be incapable of doing away with the balance-of-payments constraint on the subregion's economic growth; on the contrary, they have accentuated it. The subregion's reactivation must be environmentally sustainable and socially inclusive. If it is not, the subregion will be doomed to a future marked by intermittent outbreaks of health, financial and fiscal crises that may eventually lead to political and social instability.

As stated by Mukhisa Kituyi, Secretary-General of the United Nations Conference on Trade and Development (UNCTAD): "Building a better world requires smart actions now. The lives of future generations, indeed of the planet itself, will depend on the choices we all take over the coming months" (Kituyi, quoted in UNCTAD, 2020b). The work involved in building this future has to start now, in the midst of the battle against the pandemic. The short term and the long term are different, but they both start right now, today. One way in which countercyclical policies can make a contribution is for support measures for businesses to be made subject to certain environmental and social performance standards (see UNCTAD, 2020a). By the same token, countercyclical investment projects undertaken or promoted by the public sector should help to lay the foundations for the long-term changes in production patterns that are needed in the subregion. One aspect of pivotal importance is for the implementation of these policies to be linked to an effort to build a consensus around a thorough-going fiscal reform package -to be put into effect during the recovery - to expand the countries' fiscal space and ensure that 
the State is capable of meeting its key responsibilities in the areas of social protection and economic development. From a broader perspective, the pandemic and its impacts, which have been magnified by the inequalities and shortcomings inherent in Central America's patterns of accumulation and integration into the global economy, should be seized as an opportunity to launch a national compact for a sustainable, egalitarian development process based on a culture of rights.

Looking beyond national borders, the new development agenda for Central America necessarily entails a revitalization and intensification of regional cooperation and integration initiatives. How else could such an agenda be realized by a cluster of small economies that are wide open to trade and to world capital markets but have very small domestic markets and whose production sectors and innovation systems are far removed from the leading edge of global value chains? Central American integration has been a very active process for some time now, despite some obstacles and setbacks, as is demonstrated by the fact that nearly a third of its trade is intraregional. Leveraging this process will be a vital step forward on the path to a sustainable, inclusive form of development. And the subregion can already start moving in this direction by implementing countercyclical policies and focusing investments and incentives on strategic activities or areas in order to shift the production matrix towards greater environmental sustainability and equality. The transition to what is commonly referred to as the "green economy" opens up vast opportunities for regionally coordinated cooperation and investment in the private and public sectors that can set up and maintain a new cycle of change in production patterns and economic growth. The list of possibilities is almost endless. To name just a few of the steps that could be taken, agreements could be reached on taxation, the selective attraction of foreign direct investment, the circulation of short-term capital, migration and the strategic production of certain types of products. Over a longer time horizon, agreements could be arrived at in such areas as the modernization of the health system's infrastructure, clean energy, public transport, science, technology and innovation, and fiscal coordination.

Yet even if the integration process is reactivated soon, the subregion cannot see this process through to fruition on its own without a change in the stance taken by the international economic and financial community. Public-sector revenues and expenditures are very limited and cannot possibly cover all the social protection and development promotion needs of the subregion. Central America can only free itself from the inequality, environmental degradation and stagnation trap in which it finds itself if it can draw on strong support from the international community, especially in connection with the recovery of the economy and world trade, on the one hand, and the flow of resources from international financial institutions, on the other. In order to drive such a recovery, developed-country macroeconomic policies must remain firmly on the side of fiscal and monetary variables until consumption and particularly private investment strengthen once again. The relevant international agencies must also have the political conviction and funds to provide Central America with the necessary financial support. As noted recently by UNCTAD (2020a y 2020b), the developing world is looking at a deficit of between US\$ 2 trillion and US\$ 3 trillion over the next 18 months as a consequence of the pandemic.

More specific recommendations regarding the international financial architecture required to find a path out of the pandemic and embark on a new sustainable, inclusive development agenda for Central America can be based on four recent proposals put forward by UNCTAD: (i) significantly increase the use of special drawing rights (SDRs) to support developing countries' national strategies; (ii) launch a Marshall Plan for global health recovery to be financed on a tripartite basis with development cooperation resources and multilateral agency funding combined with a renewed effort under the Base Erosion and Profit Shifting (BEPS) initiative of the Organization for Economic Cooperation and Development (OECD) to reduce tax avoidance and evasion; (iii) set up a multinational credit rating agency under government control to take the place of the extremely powerful rating agencies now operating in the market and open up access to much more objective records that reflect the interests of developing countries as well as those of financial corporations; and (iv) establish a global debt authority 
to set up a broad, transparent international legal and institutional mechanism for instituting automatic temporary suspensions of sovereign debt repayments in times of crisis and managing restructurings fairly, efficiently and transparently. ${ }^{13}$

In closing, we would like to highlight two fundamental lessons to be learned from this pandemic. The first is that the State needs to be restored to its rightful place as a key, irreplaceable actor in the definition of the development agenda, the identification of crucial obstacles or constraints and the mobilization of resources for surmounting those hurdles. The second is the importance of reassessing how we view the public sector in relation to the private sector. During these past few months, when the cities and peoples of the subregion and the entire world have been living through such dramatic events, we are reminded that the health of all depends on the health of the most vulnerable among us. The pandemic has made the absence of anything that could be likened to a social welfare system glaringly clear. ${ }^{14}$ It has laid bare agonizing inequalities in something so basic as access to drinking water and adequate food, not to mention access to a quality education, a high standard of health care and decent employment. These inequalities are social wounds whose causes are rooted in long-standing inequities in the distribution of the fruits of growth. These wounds are reopened each and every day with the complicit silence and indifference of those who have the largest share of those fruits, and the pandemic has suddenly made this clear in a very dramatic way. This situation makes it imperative to enter into a national - and regional - compact of the kind described above. Without such a compact, the future of Central America will be nullified for vast contingents of its poor, marginalized and vulnerable people and, if that comes to pass, for all those who wish to live in a civilized society.

\section{Bibliography}

Alesina, A., C. Favero and F. Giavazzi (2019), Austerity: When it Works and When it Doesn't, Princeton, Princeton University Press.

Bank of Guatemala (2020), "La Junta Monetaria por unanimidad reduce en 25 puntos básicos la tasa de interés líder de política monetaria", Boletín de Prensa, Guatemala City, 25 June.

Barbosa, N. and others (2020), "América Latina frente al Gran Apagón”, El País, 6 May [online] https://elpais. com/economia/2020-05-06/america-latina-frente-al-gran-apagon.html.

Castellani, F. and others (2020), El impacto del COVID-19 en las economías de la región, Inter-American Development Bank (IDB) [online] https://publications.iadb.org/es/el-impacto-del-covid-19-en-laseconomias-de-la-region-centroamerica.

Central Bank of Honduras (2020), "El Banco Central de Honduras revisa el programa monetario 2020-2021 y aprueba una nueva reducción en su tasa de política", Boletín de Prensa, No. 42/2020, Tegucigalpa, 31 July.

Central Bank of the Dominican Republic (2020), "Entorno internacional" [online] https://www.bancentral.gov. do/a/d/2585-entorno-internacional.

ECLAC (Economic Commission for Latin America and the Caribbean) (2020a), Estudio económico de Centroamérica y la República Dominicana en 2019 y perspectivas para 2020 (LC/MEX/TS.2020/29), Mexico City.

(2020b), Fiscal Panorama of Latin America and the Caribbean, 2020 (LC/PUB.2020/6-P), Santiago.

(2020c), "The effects of the coronavirus disease (COVID-19) pandemic on international trade and logistics", COVID-19 Special Report, No. 6, Santiago, 6 August.

(2020d), "Addressing the growing impact of COVID-19 with a view to reactivation with equality: new projections", COVID-19 Special Report, No. 5, Santiago, 15 July.

_-(2020e), "Sectors and businesses facing COVID-19: emergency and reactivation", COVID-19 Special Report, No. 4, Santiago, 2 July.

- (2020f), "The social challenge in times of COVID-19", COVID-19 Special Report, No. 3, Santiago, 12 May.

\footnotetext{
${ }^{13}$ For a detailed description of these initiatives, see UNCTAD (2020a).

${ }^{14}$ For an analysis of the features that a social welfare system should have that makes specific reference to Central America and Mexico, see ECLAC (2020a and 2020h).
} 
(2020g), "COVID-19 Observatory in Latin America and the Caribbean: economic and social impact" [online] https://www.cepal.org/en/topics/covid-19.

(2020h), Aprender de la historia, atender la emergencia, repensar el futuro. México, Centroamérica y el Caribe frente a la pandemia: diagnóstico y perspectivas (LC/MEX/TS.2020/17/Rev.2), Mexico City. (2020i), CEPALSTAT [online database] http://interwp.cepal.org/cepalstat/portada.html?idioma=english.

ICEFI (Central American Institute for Fiscal Studies) (2020a), Perfiles Macrofiscales de Central America, No. 13, Guatemala, April.

(2020b), "Estimación de la situación fiscal de Central America al final de 2020", Notas de Coyuntura, No. 05-2020, Guatemala, July.

IMF (International Monetary Fund) (2020), "Policy Responses to COVID-19", [online] https://www.imf.org/ en/Topics/imf-and-covid19/Policy-Responses-to-COVID-19 [consultation date: 18 September 2020].

Matarrita, A. and R. Romero (2020), "Políticas económicas implementadas en la región CAPARD para contrarrestar el impacto del COVID-19", Notas Económicas Regionales, No. 114, San José, Executive Secretariat of the Central American Monetary Council, June.

Ministry of Economic Affairs and Finance of Panamá (2020), "MEF presenta proyecto de Presupuesto General del Estado 2021 por B/. 24.088.9 millones a la Asamblea Nacional", 30 July [online] https://www.mef. gob.pa/2020/07/mef-presenta-proyecto-de-presupuesto-general-del-estado-2021-por-b-24-088-9millones-a-la-asamblea-nacional/.

Ministry of Finance of Costa Rica (2020), "Presupuesto Nacional de la República" [online] https://www. hacienda.go.cr/contenido/12487-presupuesto-nacional-de-la-republica.

Ministry of Finance of El Salvador (2020), Estimación de los costos económicos, sociales, fiscales y medidas adoptadas en el marco de la pandemia COVID-19, San Salvador, April.

Ministry of Finance of Honduras (2020a), "Lineamientos de política presupuestaria 2021-2023" [online] https:// www.sefin.gob.hn/formulacion-y-aprobacion/.

_ (2020b), "Normas de ejecución presupuestaria (disposiciones generales)" [online] https://www.sefin.gob. hn/formulacion-y-aprobacion/.

Ministry of Public Finance of Guatemala (2020), "Proyecto de Presupuesto" [online] https://www.minfin.gob. gt/index.php/proyecto-de-presupuesto.

Mooney, H. and M. Zegarra (2020), "Extreme outlier: the pandemic's unprecedented shock to tourism in Latin America and the Caribbean", Policy Brief, No. 339, Washington, D.C., Inter-American Development Bank (IDB), July.

Panico, C. (2020), "La coordinación de las políticas económicas en los tiempos del coronavirus", Economía UNAM, No. 51, Mexico City, National Autonomous University of Mexico (UNAM).

SECMCA (Executive Secretariat of the Central American Monetary Council) (2020), SECMCADATOS [online database] http://www.secmca.org/secmcadatos/.

SIECA (Secretariat for Central American Economic Integration) (2020), Sistema de Estadísticas de Comercio de Central America [online database] http://www.sec.sieca.int/.

Skidelsky, R. (2019), "Has austerity been vindicated?", Project Syndicate, 22 May [online] https://www. project-syndicate.org/commentary/budget-deficits-austerity-growth-alesina-keynes-by-robert-skidelsky2019-05?barrier=accesspaylog.

Skidelsky, R. and N. Fraccaroli (eds.) (2017), Austerity vs Stimulus: the Political Future of Economic Recovery, Cham, Springer International Publishing.

The Economist (2020a), "El Salvador" [online] https://country.eiu.com/el-salvador.

(2020b), "Guatemala" [online] https://country.eiu.com/guatemala. (2020c), "Nicaragua" [online] https://country.eiu.com/nicaragua.

UNCTAD (United Nations Conference on Trade and Development) (2020a), Trade and Development Report 2020 (UNCTAD/TDR/2020), Geneva.

(2020b), 'Covid-19: UNCTAD warns of 'lost decade' if austerity becomes countries' winning policy mindset", 22 September [online] https://unctad.org/press-material/covid-19-unctad-warns-lost-decadeif-austerity-becomes-countries-winning-policy.

World Bank (2020), The Economy in the Time of Covid-19. LAC Semiannual Report, Washington, D.C., April. 